\title{
Accessible Information and Constitutional Democracy: Who Counts?
}

\author{
Jennifer Raso*
}

Accessible information is an essential resource for equal, meaningful participation in the public life of a democratic society. ${ }^{1}$ Such information is particularly vital for the effective functioning of all three branches of government in our constitutional democracy: the administrative branch, which creates government policy and holds state actors accountable to the public; the legislative branch, which scrutinizes old and creates new legislation; and the judicial branch, which reviews the acts of the legislative and executive branches. For the law-reform processes of each branch to effectively foster the informed creation and critique of public law and policy, we require reliable, accessible data depicting the diversity of individuals who make up the broader Canadian public. $^{2}$

Beyond this practical purpose, accessible information plays an expressive role as it constitutes a particular notion of the Canadian public. ${ }^{3}$ The data created by national population censuses and assembled in welfare reports has the power to "nominat $[\mathrm{e}]$ into existence" certain groups of people and, conversely, to "refus[e] to name" others. ${ }^{4}$ Such information not only represents the public, it also creates the public, as it stands in for the public at all levels of government. By communicating who we are as a society and how we are changing, census information and welfare reports shape our understanding of ourselves our laws, policies, government, and place in the world.
Recent federal changes to the collection, production, and distribution of accessible information have had devastating consequences for democratic governance in Canada. Budget cuts and structural changes to information-producing agencies such as Statistics Canada and the National Council of Welfare not only hinder informed debate and dissent about the role of the state vis-à-vis all of its members, but also entrench a new image of the Canadian public. This new image appears to be out of touch with reality, however, because it depicts Canadians as increasingly middle class and equal at a time when experts observe that socioeconomic inequality is intensifying. ${ }^{5}$

The elimination of the mandatory longform census and the National Council of Welfare may, on first glance, seem to be examples of the downsizing and privatization typically associated with neoliberalism. Yet, as this paper illustrates, neoliberalism's commitment to continuously improving the efficiency and effectiveness of government operations actually requires the production of a certain amount of accurate demographic data. Indeed, the transformation of both Statistics Canada and the National Council of Welfare seems instead motivated by libertarian populism, a political ideology distinct from neoliberalism that promotes governance by and for a mythical, folksy, average Canadian. As I demonstrate below, libertarian populism is more than just a rhetorical strategy, as it inspires insti- 
tutional reforms that reduce the availability and reliability of data about marginalized members of society, including newcomers, racialized minorities, women, indigenous peoples, and people living in poverty. Targeted cuts, such as the reduction in the scope of data collected by Statistics Canada and the defunding of the National Council of Welfare, have particularly destructive consequences for the democratic participation of members of these groups. ${ }^{6}$

In what follows, I examine the consequence of reduced access to such information for democratic governance and for Canadian society more broadly. My focus is not on the data at issue in access to information scholarship. ${ }^{7}$ Rather, I am concerned with unsorted, raw demographic data and the knowledge that is produced from it and synthesized in the reports of government agencies. My analysis assumes that such information should be created by state agencies, as they are well-positioned to gather data and produce reports tracking the well-being of vulnerable populations or comparing the effectiveness of complex government benefits programs. These agencies have the institutional authority and resources to collect, analyze, and share this information and the corresponding obligation to be accountable to the Canadian public.

This paper proceeds in three parts. The first part compares the role and function of neoliberalism and libertarian populism as ideologies of governance. While neoliberalism relies on representative data to reform government agencies from within, libertarian populism rebrands the Canadian public, rhetorically and statistically, by prompting the collection and production of a narrower range of demographic data. The second part reviews recent changes to Statistics Canada and the National Council of Welfare, two federal agencies responsible for collecting, analyzing, and producing substantial information detailing the socioeconomic features of the Canadian public and the influence of social programs. Finally, the third part explores how the elimination of the 2011 mandatory long-form census and the closure of the National Council of Welfare conflict with neoliberalism's concern for efficiency and continuous improvement.
Instead, by restricting who counts to a narrow mid-section of people, these changes advance libertarian populist politics and further marginalize those people who do not fit the politically and culturally privileged archetype of the average Canadian.

\section{Who and what count: neoliberal and libertarian populist ideologies}

As an ideology, neoliberalism targets the institutions and techniques of governance, transferring authority between public and private agencies and reforming public agencies from within through the use of private-sector management tools. Neoliberal-inspired reforms have successfully downloaded and uploaded state responsibilities between different levels of government, arm's-length public agencies, and private actors. ${ }^{8}$ By rebalancing governance responsibilities between agencies, neoliberalism centralizes the authority of those state institutions that protect citizens from what they are presumed to fear (rising crime rates, terrorism, declining morals $)^{9}$ and scatters the responsibilities of agencies that it deems duplicative or inefficient among local governments, private agencies, charities, and academic institutions. ${ }^{10}$ Neoliberalism also transforms public agencies from the inside by introducing private-sector management techniques (e.g. performance targets, auditing, surveillance) into agencies responsible for tasks that range from infrastructure procurement to social service delivery. ${ }^{11}$ As a result of these efficiencypromoting governance techniques, neoliberalism also transforms citizens, as public agencies approach members of the public as consumers rather than social citizens. ${ }^{12}$

By contrast, libertarian populism focuses squarely on who is (or should be) participating in democratic governance rather than which techniques and institutions govern. Accordingly, libertarian populism uses rhetorical strategies rather than management techniques to unseat commonly held beliefs about who we are as Canadians and which of us are legitimate participants in democratic governance. As distinct from neoliberalism, libertarian populism blends 
commitments to small government with concerns about the freedom and political interests of the so-called "little guy," "average Joe," or "taxpayer." ${ }^{13}$ The political subject of libertarian populist ideology is neither "little" nor "average," however; instead, these terms stand in for privileged property owners and "old stock Canadians." ${ }^{4}$ Libertarian populism pits the needs and desires of these political subjects against "special interests" or "elites" to make implicit claims about who legitimately participates in democratic governance.

The elites singled out by this ideology are not powerful business executives or corporate lawyers, ${ }^{15}$ but policy-makers and academics who advocate for evidence-based public policy and often support redistributing economic and political opportunities to socially excluded persons. By casting these concerns as the special interests of an elite group, libertarian populism advances a form of democratic governance by and for an imaginary average citizen that does not represent Canada's diverse public. ${ }^{16}$ Accordingly, libertarian populist rhetoric privileges dominant interests while simultaneously obscuring the power these interests exercise. ${ }^{17}$ When it inspires reforms to information-producing agencies, libertarian populism becomes more than a rhetorical strategy and effectively erases significant groups of people from the public record. As a result, those individuals who do not fit the narrow "average Joe" archetype are further marginalized.

\section{Transforming who counts: Statistics Canada and the National Council of Welfare}

Claims to democratic participation and representation are supported or undermined by the activities of agencies that produce, analyze, and distribute data tracking social and economic inequality across Canada. Thus, the federal government's cancellation of the 2011 mandatory long-form census (MLFC) and elimination of the National Council of Welfare in 2012 disrupt perceptions of who counts as member-participants within our constitutional democracy.

\section{a. Statistics Canada and the Long-Form Census}

The census has long played a central, contested role in tracking the changing demographics of Canadian society. ${ }^{18}$ Census-taking has always been political, from its growth and standardization as a tool of colonial administration in the mid-1800s ${ }^{19}$ to its evolution as a mechanism for collecting increasingly broad demographic data in the $20^{\text {th }}$ century. ${ }^{20}$ Today, the census remains deeply connected to beliefs about the value of representative government and evidence-based public policy. ${ }^{21}$

Since its creation as an arm's-length agency of the federal government in 1971, Statistics Canada has administered two mandatory censuses every five years: the short-form and long-form censuses. ${ }^{22}$ The mandatory short-form census was distributed to $80 \%$ of Canadian households and included eight questions on topics such as household size and the relationship between household members. The MLFC was distributed to the remaining $20 \%$ of households and contained between 50 and 60 questions on education, income, ethnicity, disability, language use, and paid and unpaid labour. ${ }^{23}$ Though both the short and long-form censuses were mandatory, with related statutory penalties for those who refused to complete them, few individuals were ever prosecuted and those who were often had their cases resolved informally. ${ }^{24}$

Census data is a key evidentiary resource for policy and law reform initiatives. A range of actors inside and outside of government regularly rely on census-generated data for initiatives as diverse as predicting future demands for public transit or health care services and selecting the new location of a corporate office. ${ }^{25}$ Statistics Canada's reports are also vital for law reform activities including litigation challenging the constitutionality of government law and policy, ${ }^{26}$ ministerial reports examining proposed legislation, ${ }^{27}$ and scholarship evaluating programs to improve the well-being of vulnerable individuals. ${ }^{28}$

When the federal government announced that it would eliminate the 2011 MLFC and 
replace it with a voluntary national household survey (NHS), it mobilized libertarian populist rhetoric about protecting the freedom and privacy of ordinary Canadians. The government's main reason for introducing a voluntary longform census was that a voluntary survey, which people could refuse to complete, would respect Canadians' privacy. ${ }^{29}$ To illustrate the MLFC's intrusiveness, government officials pointed to census questions measuring socioeconomic status, such as those tracking the number of bedrooms in one's home, and suggested that it was improper to "force Canadians to divulge detailed personal information under threat of prosecution." ${ }^{30}$ This concern appears overstated, however, as few people were ever prosecuted for not completing the MLFC. ${ }^{31}$

The reaction to the MLFC's elimination was swift and dramatic, with public and private sector representatives disputing the value and reliability of a voluntary survey. The federal Industry Minister suggested that the NHS would offer a picture of the Canadian population that was as accurate as the MLFC because it would survey a larger number of households. ${ }^{32}$ However, economists, sociologists, and even Statistics Canada's Chief Statistician all disputed the claim that a voluntary census could produce reliable representative data. ${ }^{33}$ Instead, these experts demonstrated that the NHS would likely produce biased data because high- and low-income individuals tend to not respond to voluntary surveys while middle-income individuals respond in larger numbers. ${ }^{34}$ As a voluntary survey, the NHS would thus not collect data from a representative, random sampling of the Canadian population, but from a subsection of the people who do respond to voluntary surveys: a predominantly white and middle class group resembling libertarian populism's ordinary or average Canadian. ${ }^{35}$ Despite three court challenges aimed at reinstituting the $\mathrm{MLFC}^{36}$ and the in-protest resignation of the Chief Statistician, ${ }^{37}$ the voluntary NHS was conducted in 2011 along with the mandatory shortform census.

The 2011 census produced less robust and less representative data on Canada's population, yet cost more to conduct than prior cen- suses. The short-form census gathered data on Canadians' age, sex, marital status, and language use, ${ }^{38}$ while other questions collecting important demographic information were left to the voluntary NHS including questions about respondents' ethnic or national origin, disability, indigenous ancestry, and household income. ${ }^{39}$ Some questions previously included in the MLFC, such as those tracking the gendered division of paid and unpaid labour, disappeared entirely. ${ }^{40} \mathrm{Com}$ pared to the previous MLFC, the 2011 NHS was distributed to a larger number of households and cost \$22 million more to carry out. ${ }^{41}$ Because its non-response rate averaged $26 \%$ and exceeded $50 \%$ in some rural communities, ${ }^{42}$ experts criticized the NHS' data as highly unreliable.

Notably, the 2011 census data shows a shrinking income gap between rich and poor Canadians that is not reflected in federal income tax data from the same year, ${ }^{43}$ likely because fewer low- and high-income individuals completed the voluntary NHS. ${ }^{44}$ Scholars who track the racialized and gendered distribution of poverty have expressed concern that these unreliable census figures may be used to support claims that Canadian society is becoming more economically equal and increasingly homogenous at a time when inequality seems to be increasing. ${ }^{45}$ Although the MLFC was reinstated for 2016, the data produced by the voluntary NHS leaves less reliable evidence available for democratic debate and establishes a dubious official record of a more homogeneous Canadian public.

\section{b. National Council of Welfare}

The elimination of the National Council of Welfare also demonstrates how changes to information-producing agencies, particularly those with a consultation mandate, effectively narrow participation in democratic governance. Established as an arm's-length body in 1969, the National Council of Welfare was legislatively mandated to provide the federal government with expert advice on poverty issues. ${ }^{46}$ As part of this mandate, the Council produced authoritative annual welfare reports comparing welfare rates across Canada and analyzing the interaction between provincial welfare programs and federal benefits. Other Council reports established poverty lines, 
compiled demographic information about welfare recipients, and proposed policies to reduce poverty and improve the well-being of people living in poverty. Preparing these documents required an expert, nuanced analysis of poverty as a complex phenomenon affecting racialized minorities, newcomers, indigenous peoples, persons with disabilities, and sole-support mothers, among others.

Council reports are central resources for multi-disciplinary research on poverty and for law reform initiatives within and outside of government agencies. Scholars examining public health policy, the role of kinship networks in alleviating poverty, and the effectiveness of welfare-to-work reforms have all built their studies on Council reports. ${ }^{47}$ Additionally, Council reports are vital to federal and provincial reviews of social programs and for NGO submissions to the committees and commissions conducting these reviews. ${ }^{48}$ Council reports have also been important evidentiary supports in constitutional litigation to improve the situations of women who face poverty upon marriage breakdown ${ }^{49}$ or accused persons who are denied bail in criminal proceedings. ${ }^{50}$

Unlike the elimination of the MLFC, which was justified with dramatic references to the spectre of government in the bedrooms of Canadians, the Council was abolished by a single cut buried within a 450-page omnibus budget bill. This bill reduced the Council's funding by $\$ 1.1$ million - the Council's entire budget. However, this cut was overshadowed by the mass of other changes the budget proposed, such as reduced protections for fish and other aquatic species, relaxed environmental assessment rules, and increased restrictions on the political activities of charitable organizations. ${ }^{51}$ The federal government suggested that the Council needed to be closed to reduce duplication, as NGOs were already providing high-quality independent research on poverty issues. ${ }^{52}$ This explanation discounted the Council's centrality, erroneously casting it as duplicative and dispensable at a time when NGOs' own research on poverty issues relied heavily on Council reports. Producing an equivalent range of reports is realistically beyond most NGOs' scope and expertise, given the time and resources required to obtain the necessary methodological skills and nation-wide data. ${ }^{53}$ More importantly, no other agency has since assumed the Council's advisory role, leaving a landscape where NGOs with expertise on poverty issues must compete with constituents and lobbyists for the attention of ministers and other legislators while relying on a smaller, less representative pool of data. ${ }^{54}$

\section{The practical and expressive effects of reduced access to public information}

By reducing the diversity of who counts as members of the public in official state documents, recent changes to information-producing agencies hinder participatory democratic governance. The elimination of the MLFC and the Council reinforces the libertarian populist notions that appear to have inspired these cuts. Further, an un(der)representative public record allows government officials to remain ignorant of how wealth and privilege are becoming concentrated within a tiny subset of the Canadian population and to avoid re-evaluating the responsibilities of democratic institutions in light of growing diversity and deepening inequality. ${ }^{55}$

The decision to eliminate the MLFC and National Council of Welfare thwarts the federal government's ability to continuously improve and streamline government agencies, as this neoliberal goal requires representative data on government services and their consumer-stakeholders. ${ }^{56}$ To realize ongoing efficiency gains, public sector managers and policy-makers must be able to learn from previous successes and failures and predict future challenges. Thus, continuous improvement depends on extensive, reliable data about government programs and the individuals they serve. Eliminating the representative MLFC and replacing it with a more expensive, less reliable voluntary NHS is confounding from a neoliberal perspective, especially because a comparable data set was not (and arguably cannot be) produced by the private sector. ${ }^{57}$ Indeed, neoliberal ideology actually better explains the 
recent reintroduction of the MLFC rather than its demise in 2011.

The Council's closure is also puzzling from a neoliberal perspective, as its advisory function and welfare reports are essential for reviewing and improving social program delivery across Canada. Although a private agency has begun producing welfare rate reports, they are less extensive and published less frequently. ${ }^{58}$ Further, no private agency has begun analyzing the broader issues examined by the Council's other reports, such as how to reduce poverty or improve the well-being of those living in poverty. Eliminating the Council thus makes little sense from a neoliberal perspective, especially given the relatively meagre amount of funding that the Council needed to continue producing and distributing complex reports and advising the federal government. Not only do changes to information-producing agencies impede continuous improvement activities, they entrench a more homogenous vision of the public within official records. These changes have both practical and expressive effects that, together, restrict who has a legitimate claim to participate in democratic governance.

\section{a. Practical, institutional effects}

Changes at Statistics Canada and the elimination of the National Council of Welfare have reduced the quality and availability of official public data detailing Canada's demographics and social programs. The data that is most accessible to legislators, policy-makers, and the public contain gaps that make it appear that Canadian society is becoming more homogenous. When combined with the removal of previously published data from government websites, these gaps make it difficult to access data representative of the entire Canadian population.

Data gaps and reliability problems are largely the product of changes to the census and are amplified by the Council's elimination. The NHS' demographic data contains two distinct sets of holes. First, holes exist in the data collected (or not collected) from those at the high and low ends of the income spectrum. As noted above, Canada's richest and poorest residents tend to not respond to voluntary surveys, so they are notably absent from the 2011 census figures. ${ }^{59} \mathrm{~A}$ second, geographically specific set of holes exists in the data on rural and impoverished communities where residents responded to the voluntary NHS in such low numbers that they have effectively disappeared from published census data. ${ }^{60}$ To compound these smaller data gaps, the data produced by the NHS cannot be read against previous or future MLFC data because, as the product of a voluntary survey, NHS figures represent a different group of Canadians than is represented in MLFC data. This lack of comparability essentially means that a large data gap exists for the 2011 census year, making it nearly impossible to determine whether the federal government's response to the 2008 economic downturn reduced or deepened social and economic inequality in Canada. ${ }^{61}$

The elimination of the MLFC and the Council also impedes members of the public from accessing reliable data and using it to evaluate and debate the state of Canada's constitutional democracy. Scholars, policy-makers, and corporations may be well-positioned to access privately-held data collections or produce their own supplementary data, ${ }^{62}$ but the elimination of the MLFC and the Council has placed representative information about the Canadian public out of reach for many others. The elimination of the Council is especially detrimental, as new welfare rate reports are now produced infrequently and the Council's previous reports are harder to access since, after the Council's closure, all but two of its reports have been removed from federal government websites. ${ }^{63}$ Other Council reports are now scattered between university libraries, which often require a fee for access, and privately-maintained collections, making it more difficult for members of the public to access reliable demographic and social program data. Those individuals who want to use data must choose between relying on unreliable 2011 census data or outdated but higher quality 2006 data, purchasing whatever privately-held data they can afford, or waiting until new census data or intermittently-produced welfare reports become available. Taken together, the practical effects of census changes and the Council's clo- 
sure include an entrenched unrepresentative picture of Canadian society and increased obstacles facing scholars, social justice advocates, and others who might challenge the increasingly uniform, middle class picture of Canadian society that these reforms produced. ${ }^{64}$

\section{b. Expressive, ideological effects}

The changes to information-producing agencies also send powerful messages about membership in Canadian society, state accountability, and the value of information-producing agencies for democratic governance. By eliminating the MLFC and the National Council of Welfare, the federal government signaled that a narrower range of people belong as members and subjects within Canada's constitutional democracy. Marginalized individuals become invisible as a result of gaps in census data and the removal of Council reports from government-maintained websites, especially as the few easily accessible reports detail social assistance rates rather than the experiences of people living in poverty. Viewed cumulatively, these changes not only erase a wide range of vulnerable individuals from public records, but also demonstrate that such individuals are erasable. Yet, while marginalized people may be absent from the official records of information-producing agencies, they remain subject to intimate surveillance by other state agencies. These alternative data collection practices discipline and regulate those who do not fit the ordinary Canadian archetype, scrutinizing the lives of those who rely on government benefits or who are disproportionately targeted by immigration or criminal law enforcement initiatives. ${ }^{65}$ Through these uneven data collection practices, those on the margins become the objects of regulation rather than welcome participants in the shared enterprise of democratic governance.

Further, when official government records communicate a vision of an increasingly uniform public, they may suggest a more casual approach to democratic governance. If the public is understood to be a relatively homogenous group of people with harmonious interests, then legislators, policy-makers, and judges may be less likely to consider empirical data or to weigh competing public interests when making decisions. Instead, government representatives may be more inclined to rely on anecdotal evidence, assuming that it adequately reflects the experience of others. ${ }^{66}$ In this way, changes to information-producing agencies create an evidentiary foundation that implicitly supports democracy by and for the mythical ordinary Canadian and enables a willful blindness to the complex needs of a heterogeneous public. Moreover, as official public records depict a more uniform image of Canadians, they undermine the value of representative public information and the agencies that produce it. If the public is understood to be relatively homogenous and demographic data is framed as an elitist concern, these changes tacitly support the claim that the privacy and financial costs of producing rich, representative public data are too high.

\section{Conclusion: who counts?}

The ways in which libertarian populism has substantially altered public information-producing institutions discount marginalized individuals as members of the public and devalue their role in democratic governance. The changes to Statistics Canada and the National Council of Welfare undermine our ability to question whether the well-being of all members of society is adequately supported, as the information needed to answer such questions becomes increasingly inaccessible or disappears entirely. Because libertarian populism effectively pitches academics and social justice advocates against purportedly average Canadians, it is tricky to challenge libertarian populist politics without unintentionally affirming the view that information-producing agencies are elitist enterprises. ${ }^{67}$

In response, we must insist on the diverse reality of contemporary Canadian society. This project is as much a social project as it is a political or legal one. The prospect of governance by and for a mythical little guy or average Canadian is deeply disconnected from a polity characterized by regional, indigenous, cultural, and socioeconomic pluralism. When government officials use libertarian populist discourse to reform information-producing agencies, they bolster 
a form of government-by-anecdote rather than one committed to consulting with and incorporating the concerns of Canada's heterogeneous public. To counter libertarian populism's practical and symbolic effects, we must reconsider and reaffirm the value of richly participatory democracy, the significance of public institutions, and the need to (re)balance power between the purportedly ordinary Canadians and everyone else.

\section{Endnotes}

* SJD Candidate, Faculty of Law, and Junior Fellow, Centre for Criminology and Sociolegal Study, University of Toronto. This paper has greatly benefited from discussions with participants at the David Asper Centre's Symposium on the State of Canada's Constitutional Democracy and at the Gendered Dissent, Democracy and Law workshop hosted by the Institute for Feminist Legal Studies at Osgoode Hall Law School, and is an abridged version of an article published in (2016) Volume 12 Journal of Law and Equality. I am grateful for the support of the Social Sciences and Humanities Research Council.

1 Anne-Marie Gingras, "Access to Information: An asset for democracy, or ammunition for political conflict, or both?" (2012) 55:2 Can Pub Pol'y 221.

2 Debra Thompson, "The Politics of the Census: Lessons from Abroad" (2010) 36:3 Can Pub Poly 377 at 381 [Thompson, "The Politics of the Census"].

3 William Ramp \& Trevor W Harrison, "Libertarian Populism, Neoliberal Rationality, and the Mandatory Long-form Census: Implications for Sociology" (2012) 37:3 Can J Sociology 273 at 286 [Ramp \& Harrison].

4 David I Kertzer \& Dominique Arel, "Censuses, identity formation, and the struggle for political power" in David I Kertzer \& Dominique Arel, eds, Census and Identity: The Politics of Race, Ethnicity, and Language in National Censuses (Cambridge: Cambridge University Press, 2001) 1 at 23; Debra Thompson, "Making (mixed-)race: census politics and the emergence of multiracial multiculturalism in the United States, Great Britain and Canada" (2012) 35:8 Ethnic \& Racial Studies 1409.

5 David A Green, W Craig Riddell \& France StHilaire, eds, Income Inequality: The Canadian Story
(Montréal: Institute for Research on Public Policy, 2016); Thomas Piketty, Capital in the TwentyFirst Century, translated by Arthur Goldhammer (Cambridge, Mass: Harvard University Press, 2014).

6 Canada, Parliament, Standing Committee on the Status of Women, Changing the Long-Form Census- Its Impact on Women's Equality in Canada, 40th Parl, 3rd session (February 2011) [Canada, Census Impact on Women's Equality].

7 Vincent Kazmierski, "Accessing Democracy: The Critical Relationship between Academics and the Access to Information Act" (2011) 26:3 Canadian J L \& Society 613.

8 Harry W Arthurs, "Public Law in a Neoliberal Globalized World: The Administrative State Goes to Market (and Cries 'Wee, Wee, Wee' All the Way Home)" (2005) 55:3 UTLJ 797.

9 Jonathan Simon, Governing Through Crime: How the War on Crime Transformed American Democracy and Created a Culture of Fear (New York: Oxford University Press, 2007); Dianne L Martin, "Both Pitied and Scorned: Child Prostitution in an Era of Privatization" in Brenda Cossman \& Judy Fudge, Privatization, Law and the Challenge to Feminism (Toronto: University of Toronto Press, 2002) 355 [Cossman \& Fudge, Challenge to Feminism].

10 Judy Fudge \& Brenda Cossman, "Introduction: Privatization, Law and the Challenge to Feminism" in Cossman \& Fudge, Challenge to Feminism, ibid at 16-18 [Fudge \& Cossman, "Introduction"].

11 Michael Power, The Audit Society: Rituals of verification (Oxford: Oxford University Press, 1997); Sally Engle Merry, Kevin E Davis \& Benedict Kingsbury, eds The Quiet Power of Indicators: Measuring governance, corruption, and rule of law (New York: Cambridge University Press, 2015) [Power]; Jody Freeman \& Martha Minow, eds, Government by Contract: Outsourcing and American Democracy (Cambridge, Mass: Harvard University Press, 2009).

12 Wendy Brown, "Neo-liberalism and the End of Liberal Democracy" (2003) 7:1 Theory and Event; Lawrence M Mead, Beyond Entitlement: The Social Obligations of Citizenship (New York: Free Press, 1986).

13 Ramp \& Harrison, supra note 3 at 286; See also Ronald P Formasino, The Tea Party: A Brief History (Baltimore: Johns Hopkins University Press, 2012).

14 Mariana Valverde, Chronotopes of Law: Jurisdiction, Scale, Governance (Abingdon, Oxon: Routledge, 2015) at 19; Tristan Hopper, "Taking 
Stock of 'Old Stock Canadians"', National Post (15 September 2015) A4.

15 Marian Sawer \& David Laycock, "Down with Elites and Up with Inequality: Market Populism in Australia and Canada" (2009) 47:2 Commonwealth \& Comparative Politics 133 at 136-37.

16 Thompson, "The Politics of the Census", supra note 2.

17 TH Marshall, Citizenship and Social Class: and other essays (Cambridge: Cambridge University Press, 1950); Fudge \& Cossman, "Introduction", supra note 10 .

18 Brian Edward Hubner, "Aboriginal resistance, bureaucratic change and the census: 1830-2006" (2007) 7:3 Archival Science 195; James C Saku, "Aboriginal Census Data in Canada: A Research Note" (1999) 19:2 Can J Native Studies 365.

19 Bruce Curtis, The Politics of Population: State formation, statistics, and the census of Canada 1840-1875 (Toronto: University of Toronto Press, 2001) [Curtis]; Peter Skerry, Counting on the Census?: Race, group identity, and the evasion of politics (Washington, DC: Brookings Institution Press, 2000); Bernard Cohn, "The census, social structure, and objectification in South Asia" in Bernard Cohn, An anthropologist among the historians and other essays (Oxford: Oxford University Press, 1987) at 224.

20 Thompson, "The Politics of the Census", supra note 2.

21 Curtis, supra note 19.

22 The Constitution Act, 1867 (UK), 30 \& 31 Vict, c 3, s 8, reprinted in RSC 1985 Appendix II, No 5 initially required that a census be taken every 10 years. In 1956, federal policy changed so that a census would be taken every five years. Today, this five-year requirement is codified in the Statistics Act, RSC 1985, c S-19, s 19(1).

23 Fédération des communautés francophones et acadienne du Canada v Canada (Attorney General), 2010 FC 999 (QL) [FCFAC] at paras 6-9.

24 Mark Kennedy \& Mike De Souza, "Clement altered census message", Edmonton Journal (11 August 2010) A9 [Kennedy \& De Souza].

25 David A Green \& Kevin Milligan, "The Importance of the Long Form Census to Canada" (2010) 36:3 Can Pub Poly 383 [Green \& Milligan]. Statistics Canada also relies on this data to establish baselines for its other statistical reports, including its influential labour force survey and survey of household spending: Michael Darroch \& Gordon Darroch, "Commentary: Losing Our Census" (2010) 35:4 Can J Communications 609 at 612-13 [Darroch \& Darroch].
26 Statistics Canada data on Canada's "poverty line" was relied on in Gosselin v Québec (Attorney General), 2002 SCC 84, [2002] 4 SCR 429; census data on family expenditures and family composition was used in $M v H$, [1999] 2 SCR 3; Statistics Canada figures on provincial unionization rates were cited in Dunmore $v$ Ontario (Attorney General), 2001 SCC 94, [2001] 3 SCR 1016; Statistics Canada reports on persons with disabilities were relied on in Eldridge $v$ British Columbia (Attorney General), [1997] 3 SCR 624.

27 Government of Ontario, Realizing Our Potential: Ontario's Poverty Reduction Strategy 2014-2019 (Toronto: Queen's Printer, 2014) at 46 [Ontario, Poverty Reduction Strategy].

28 Sabrina Lyon \& Lorne Sossin, "Data and Diversity in the Canadian Justice Community" (2014) $11 \mathrm{JL}$ \& Equality 85; Steven Wald \& Gervan Fearon, "The Earnings Gap between Black and White workers in Canada: Evidence from the 2006 Census" (2011) 66:3 Relations industrielles 324; Nancy A Ross et al, "Relation between income inequality and mortality in Canada and in the United States: cross sectional assessment using census data and vital statistics" (2000) 320 Brit Med J 898; Francis Mitrou et al, "Gaps in Indigenous disadvantage not closing: a census cohort study of social determinants of health in Australia, Canada, and New Zealand from 1981-2006" (2014) 14 BMC Public Health 201.

29 Ramp \& Harrison, supra note 3 at 274; Margaret Walton-Roberts et al, "Why do we still need a census? Views from the age of 'truthiness' and the 'death of evidence"' (2014) 58:1 Can Geographer 34 at 42 .

30 Media Relations, "Archived - Statement on 2011 Census", Government of Canada, online: GoC <www.news.gc.ca/web/article-en. do?nid=547529> [Census Statement].

31 Kennedy \& De Souza, supra note 24; Steven Chase, "Privacy czar not consulted on plan to scrap compulsory census" The Globe and Mail (15 July 2010) A4.

32 Census Statement, supra note 30.

33 Green \& Milligan, supra note 25.

34 This point was raised at the Standing Committee on Industry, Science and Technology by Ivan Fellegi, a former Chief Statistician, who noted that people living in poverty were most likely to be underrepresented by a voluntary census. See also Marc Frenette, David A Green \& Garnett Picot, "Rising Income Inequality in the 1990s: An Exploration of Three Data Sources" in David A Green \& Jonathan R Kesselman, eds, Dimensions 
of Inequality in Canada (Vancouver: UBC Press, 2006) at 65.

35 Green \& Milligan, supra note 25 at 384.

36 FCFAC, supra note 23; Native Council of Nova Scotia v Canada (Attorney General), 2011 FC 72 (QL); Canadian Council on Social Development v Canada (Attorney General), 2012 FC 1530 (QL).

37 Kady O’Malley, “UPDATED - CensusWatch: And that's all he wrote ... Munir Sheikh resigns as Chief Statistician", CBC News (21 July 2010), online: <www.cbc.ca/newsblogs/politics/insidepolitics-blog/2010/07/censuswatch-and-thatsall-he-wrote-munir-sheikh-resigns-as-chiefstatistician.html>.

38 Order in Council 2010-1077, published in the Canada Gazette on 21 August 2010, prescribed the timing and content of the 2011 census. In response to criticism from linguistic minority communities, this OIC repealed and replaced a previous OIC to add two additional questions on language use to the mandatory short-form census.

39 Andrew Jackson, "Even a bad survey cannot blind us to income inequality", The Globe and Mail (11 September 2013), online: <www.theglobeandmail. com/report-on-business/economy/economy-lab/ even-a-bad-survey-cannot-blind-us-to-incomeinequality/article14251936/>.

40 Questions about unpaid caregiving for 2011 were only included in Statistics Canada's General Social Survey, which (as a voluntary survey) risks criticism for being as under-inclusive as the NHS: Canada, Census Impact on Women's Equality, supra note 6.

41 The NHS was distributed to 4.5 million households instead of the 2.9 million that would have received the MLFC in 2011, which contributed to its substantially higher cost: Darroch \& Darroch, supra note 25 at 612 . The total cost of the 2011 census was reportedly $\$ 652$ million, with a $\$ 22$ million increase attributed to the NHS: Tavia Grant, "Damage from cancelled census as bad as feared, researchers say", The Globe and Mail (29 January 2015) A1.

42 Because of this high non-response rate, NHS data is unavailable for some Saskatchewan and Newfoundland communities: Paul Jacobson, "Policy making suffering in Canada without the long-form census", The Globe and Mail (5 November 2014) B2 [Jacobson].

43 Tavia Grant, "Canadian income data 'is garbage' without census, experts say", The Globe and Mail (4 October 2013), online: <www.theglobeandmail. $\mathrm{com} / \mathrm{news} / \mathrm{politics/without-census-data-}$ on-canadian-income-garbage-experts/ article14701515/> [Grant, "Canadian income data is garbage"].

44 David Hulchanski et al, "Canada's voluntary census is worthless. Here's why", The Globe and Mail (4 October 2013), online: <www.theglobeandmail. $\mathrm{com} /$ commentary/canadas-voluntary-census-isworthless-heres-why/article14674558/>.

45 Sheila Block, Grace-Edward Galabuzi \& Alexandra Weiss, "The Colour Coded Labour Market by The Numbers: A National Household Survey Analysis" The Wellesley Institute (September 2014), online: $<$ www.wellesleyinstitute.com/wp-content/ uploads/2014/09/The-Colour-Coded-LabourMarket-By-The-Numbers.pdf $>$.

46 The National Council of Welfare was established as an arm's-length advisory agency by the Government Organization Act, SC 1969, 17-18 Elizabeth II c 28.

47 Chris Kaposy \& Sarah Khraishi, "A relational analysis of pandemic critical care triage protocols" (2012) 5:1 Intl J Feminist Approaches to Bioethics 70; Amber Gazso \& Susan A McDaniel, "Families by Choice and the Management of Low Income Through Social Supports" (2015) 36:3 J Family Issues 371; Nathan Berg \& Todd Gabel, "Did Canadian welfare reform work? The effects of new reform strategies on social assistance participation" (2015) 48:2 Can J Economics 494.

48 Commission for the Review of Social Assistance in Ontario, Brighter Prospects: Transforming Social Assistance in Ontario (Toronto: Queen's Printer, 2012) at 130-31.

49 Moge v Moge, [1992] 3 SCR 813.

$50 R v$ Hall, 2002 SCC 64, [2002] 3 SCR 309.

51 Bill C-38, enacted as the Jobs, Growth and Longterm Prosperity Act, SC 2012, c 19.

52 Laurie Monsebraaten, "Federal budget 2012: Ottawa axes National Council on Welfare", The Toronto Star (30 March 2012), online: <www. thestar.com/news/canada/2012/03/30/federal_ budget_2012_ottawa_axes_national_council_on_ welfare.html\#>.

53 Many of the Council's previous reports would likely be considered political advocacy under the new tax rules governing charities. Consequently, today fewer organizations are able to produce the range of reports that the Council once published: Martha Jackman \& Bruce Porter, "Introduction" in Martha Jackman \& Bruce Porter, eds, Advancing Social Rights in Canada (Toronto: Irwin Law, 2014) 1 at 18.

54 Carol Goar, "Tories stifle a voice of social justice", Toronto Star (13 April 2012) A19. 
55 Broadbent Institute, Towards a More Equal Canada: A Report on Canada's Economic \& Social Inequality (Ottawa: Broadbent Institute, 2012). Though the federal Standing Committee on Finance recently studied income inequality, its recommendations focused on keeping taxes low and avoiding "disincentives" to work: House of Commons, Standing Committee on Finance, Income Inequality in Canada: An Overview (December 2013) (Chair: James Rajotte) at 40-43.

56 Power, supra note 11; Joe Soss, Richard C Fording \& Sanford F Schram, Disciplining the Poor: Neoliberal Paternalism and the Persistent Power of Race (Chicago: University of Chicago Press, 2011).

57 Darroch \& Darroch, supra note 25.

58 Anne Tweddle, Ken Battle \& Sherri Torjman, "Canada Social Report: Welfare in Canada, 2012" Caledon Institute of Social Policy (December 2013), online: <www.caledoninst.org/Publications/ PDF/1031ENG.pdf $>$.

59 Grant, "Canadian income data is garbage", supra note 43.

60 Statistics Canada decided to publish NHS data only for regions where over $50 \%$ of NHS recipients completed the survey. Consequently, some communities have no published NHS data for 2011: Jacobson, supra note 42.

61 Michael Haan, "Counting and Contemporary Governance: Introduction to the Special Issue" (2012) 37:3 Can J Sociology 223 at 228 [Haan].

62 See Ontario, Poverty Reduction Strategy, supra note 27 at 46 .

63 The only two Council reports now available through federal government websites are "The Dollars and Sense of Ending Poverty" (September 2011), online: <www.publications.gc.ca/site/ eng/405488/publication.html> and the most recent Welfare Incomes report (updated to 2011), online: <www.hrsdc.gc.ca/eng/communities/ index.shtml $>$.

64 Johnstone $v$ Canadian Border Services Agency, 2010 CHRT 20 (CanLii), aff'd on judicial review Canada (Attorney General) v Johnstone, 2013 FC 113; aff'd 2014 FCA 110, in which a female employee with two young children challenged the CBSA's shift scheduling practices on the basis of family status. The CBSA challenged an expert witnesses proposed by the applicant, claiming that the witness could not be an expert given the lack of empirical data, such as statistics, on Canada's childcare policies and the gendered division of caregiving labour.

65 Janet Mosher et al, Walking on Eggshells: Abused Women's Experiences of Ontario's Welfare System, Final Report of Research Findings from the Woman and Abuse Welfare Research Project (Toronto: The Project, 2004); Kaaryn Gustafson, Cheating Welfare: Public Assistance and the Criminalization of Poverty (New York: New York University Press, 2011). See also James Walsh, "Watchful Citizens: Immigration Control, Surveillance and Societal Participation" (2014) 23:2 Soc \& Leg Stud 237; David M Tanovich, "E-Racing Racial Profiling" (2004) 41:4 Alta L Rev 905.

66 This phenomenon occurs in land use planning debates, with detrimental consequences for marginalized individuals: Prashan Ranasinghe \& Mariana Valverde, "Governing Homelessness Through Land-use: A Sociolegal Study of the Toronto Shelter Zoning By-law" (2006) 31:3 Can J Sociology 325.

67 Haan, supra note 62 at 228-29. 
